\title{
Peran Ekstrak Etanol Topikal Daun Mengkudu (Morinda citrifolia L.) pada Penyembuhan Luka Ditinjau dari Imunoekspresi CD34 dan Kolagen pada Tikus Galur Wistar
}

\author{
Indah Puti Rahmayani Sabirin, ${ }^{1}$ Ani Melani Maskoen, ${ }^{2}$ Bethy S. Hernowo ${ }^{3}$ \\ ${ }^{1}$ Fakultas Kedokteran Gigi Universitas Ahmad Yani Cimahi, ${ }^{2}$ Unit Penelitian Kesehatan Fakultas \\ Kedokteran Universitas Padjadjaran, ${ }^{3}$ Departemen Patologi Anatomi Fakultas Kedokteran Universitas \\ Padjadjaran Rumah Sakit Dr. Hasan Sadikin Bandung
}

\begin{abstract}
Abstrak
Luka akan menimbulkan masalah jika penanganannya kurang baik sehingga menyebabkan luka kronik. Mengkudu (Morinda citrifolia L.) merupakan tanaman khas daerah tropis termasuk Indonesia, yang buah, daun, dan akarnya sering digunakan dalam pengobatan tradisional, di antaranya untuk menyembuhkan luka. Penelitian dengan rancangan eksperimental sederhana ini bertujuan untuk mengetahui efek penggunaan ekstrak etanol daun mengkudu terhadap penyembuhan luka pada pemberian topikal, dengan melihat gambaran histopatologis yang terdiri atas sel fibroblas, infiltrasi sel inflamasi, imunoekspresi cluster of differentiation 34 (CD34), dan deposisi kolagen. Penelitian dilakukan di laboratorium Farmakologi dan Patologi Anatomi RS Dr. Hasan Sadikin Bandung pada November 2010-September 2011. Penelitian ini dilakukan pada 36 tikus dengan membuat eksisi pada punggung tikus. Kemudian tikus-tikus tersebut dibagi menjadi 2 kelompok yaitu kelompok kontrol dan perlakuan ekstrak etanol daun mengkudu topikal pada luka. Jaringan luka tiap kelompok diamati secara mikroskopis pada hari ke-3, 7, dan 14. Hasil penelitian menunjukkan penyembuhan luka kelompok perlakuan cenderung lebih baik, dilihat pada data hari ke-3, 7, dan 14 pada semua parameter. Uji statistik Mann-Whitney pada tingkat kepercayaan 95\% $(\mathrm{p}<0,05)$ untuk jumlah fibroblas, infiltrasi sel inflamasi, imunoekspresi CD34, dan kolagen berturut-turut $p=0,319 ; p=0,290 ; p=0,251 ;$ dan $p=0,245$. Simpulan, ekstrak etanol topikal daun mengkudu cenderung bermanfaat pada penyembuhan luka, walaupun secara statistik tidak bermakna. [MKB. 2013;45(4):226-33]
\end{abstract}

Kata kunci: CD34, daun mengkudu, kolagen, penyembuhan luka

\section{Role of Noni (Morinda citrifolia L.) Leaf Ethanolic Extract Topical Application on Wound Healing Examined from CD34 Immunoexpression and Collagen on Wistar Rats}

\begin{abstract}
Problems in wound healing occurred if proper care is not given and the wound develops into a chronic wound. Noni (Morinda citrifolia L.) is one of the most common plants in tropical areas, including Indonesia, which fruit, leaves dan root are used in traditional treatment, for example wound healing. This experimental research with post test-only control group design identified the effect of topical application of noni leaves ethanol extract on wound healing by examining the histopathological appearance of fibroblas count, inflammatory cell infiltration, cluster of differentiation 34 (CD34) immunoexpression, and collagen deposition. The research was performed between November 2010 until September 2011 at the Pharmacology and Pathology Anatomy laboratories of Dr. Hasan Sadikin General Hospital Bandung. Excisions were made on each back of the rat of the 36 rats that were divided into control and test groups where the test group received topical application of noni leaves ethanol extract. The wound was examined on day 3, 7, and 14 using a light microscope. The result showed a tendency of better wound healing in the test group for all parameters based on the data on day 3, 7, and 14. Mann-Whitney Test with $95 \%$ confidence interval $(\mathrm{p}<0.05)$ showed that the $\mathrm{p}$ value for fibroblast count, inflammation cell infiltration, CD34 immunoexpression and collagen subsequently were $p=0.319, p=0.290, p=0.251$, and $p=0.245$, respectively. In conclusion, topical application of noni leaves ethanol extract has a benefit on wound healing although the results are not statistically significant. [MKB. 2013;45(4):226-33]
\end{abstract}

Key words: CD34, collagen, noni leaves, wound healing

Korespondensi: Indah Puti Rahmayani S., drg., Fakultas Kedokteran Gigi Universitas Ahmad Yani Cimahi, mobile 085624329427 e-mail indah_puti_r@yahoo.com 


\section{Pendahuluan}

Proses penyembuhan luka terdiri atas fase-fase inflamasi, proliferasi, dan juga remodeling. Pada fase inflamasi ini terjadi proses vasokonstriksi, hemostasis, dan juga infiltrasi sel inflamasi. Fase proliferasi dibuktikan dengan angiogenesis, deposisi jaringan kolagen, pembentukan jaringan granulasi, dan migrasi sel epitel. Fase remodeling ditandai dengan terdapat remodeling jaringan dan kolagen, maturasi epidermis, dan pengerutan luka. Penanganan utama luka pada umumnya berupa debridemen, irigasi, dan juga pemberian antibiotik atau antiseptik. Kejadian penyembuhan luka dapat terhambat apabila kemampuan alami jaringan untuk memperbaiki diri berkurang dan penanganan yang dilakukan terhadap luka tidak baik. Kekurangan komponen penyembuhan luka ini dapat berupa ulserasi dan dehisensi. Selain itu, penyembuhan luka dapat disertai pembentukan komponen penyembuhan yang berlebihan dan sifatnya patologis seperti pembentukan sikatriks, keloid, dan hipertrofi. Penyembuhan luka yang optimal tercapai jika tidak terjadi komplikasi dalam bentuk kekurangan ataupun kelebihan komponen penyembuhan luka terutama kolagen dan sel epitel. Terdapat kekurangan atau kelebihan komponen ini dapat dilihat lebih jelas pada fase remodeling. Komplikasi penyembuhan luka yang lainnya berupa kontraksi luka yang berlebihan. ${ }^{1-4}$

Mengkudu (Morinda citrifolia L.) merupakan tanaman jenis tropis yang terdistribusi di Asia Tenggara, Pasifik, Amerika Selatan, dan Amerika Tengah. Tanaman ini dapat dimanfaatkan dari buah, daun, biji, dan bunganya. Secara empiris daun mengkudu dipergunakan sebagai kompres untuk menyembuhkan bagian kulit yang luka, sendi yang terkilir, dan juga untuk mengurangi rasa nyeri. Di beberapa daerah, infusa daunnya dikonsumsi sebagai minuman untuk pengobatan demam secara umum, pengobatan malaria, dan sebagai analgesik. ${ }^{2,5}$ Bahan aktif yang terdapat pada daunnya yaitu saponin, triterpen, tanin, alkaloid, glikosida iridoid, dan flavonoid. ${ }^{2,6,7}$ Efek utama senyawa kimia dalam daun mengkudu yang berhubungan dengan proses penyembuhan luka antara lain saponin sebagai antibakteri, tanin sebagai hemostatik serta astringensia, alkaloid berguna sebagai analgetik, dan senyawa glikosida iridoid sebagai antiinflamasi, sedangkan flavonoid sebagai antioksidan dan antiinflamasi. ${ }^{2,6-9}$

Penggunaan ekstrak etanol daun mengkudu per oral membantu mempercepat penyembuhan pada model perlukaan tikus. ${ }^{2,5}$ Daun mengkudu kering yang ditumbuk dan diaplikasikan secara topikal juga diketahui dapat mempercepat proses epitelisasipadalukainsisitikus, serta ekstrakairnya mengurangi eritema yang diakibatkan paparan sinar ultraviolet B (UVB). ${ }^{7,10}$ Daun tanaman yang mengandung flavonoid kuersetin dan rutin - yang juga dilaporkan terdapat pada daun mengkudu dapat memperbaiki proses penyembuhan luka pada fase awal yang diperlihatkan dari regulasi ekspresi vascular endothelial growth factor (VEGF) dan pembentukan kolagen tipe III. ${ }^{11}$

Kolagen merupakan protein yang terbanyak pada matriks ekstraselular kulit, dan berfungsi untuk mengisi matriks ekstraselular. Pada proses penyembuhan luka, kolagen dibentuk sejak hari ke-3 dan akan tampak nyata jumlahnya di hari ke-7 setelah luka, dan mulai stabil dan terorganisir sekitar hari ke-14.,12 Serabut kolagen dapat dibedakan dengan matriks ekstraselular lainnya secara lebih spesifik dengan menggunakan teknik pewarnaan khusus yaitu pewarnaan histokimia.

Cluster of differentiation 34 (CD34) adalah suatu protein membran, antigen endotel yang dapat digunakan sebagai penanda untuk mengukur pertumbuhan pembuluh darah baru. Pada keadaan normal, CD34 diekspresikan pada sel endotel. Pembentukan pembuluh darah baru dimulai pada hari ke-3 pascaperlukaan, kemudian meningkat, sampai akhirnya akan berkurang dan mulai stabil saat matriks ekstraselular mulai mengisi daerah yang hilang karena perlukaan sekitar hari ke-14. Pemeriksaan imunohistokimia CD34 dan protein kolagen diharapkan dapat membantu mengetahui proses penyembuhan luka pada kulit. ${ }^{3,13,14}$ Tujuan penelitian ini untuk mengetahui efek penggunaan ekstrak etanol dengan mempergunakan mengkudu pada penyembuhan luka yang diberikan topikal dengan melihat gambaran histologis.

\section{Metode}

Penelitian menggunakan 36 ekor tikus galur Wistar yang dibagi menjadi dua kelompok yaitu 18 kelompok kontrol dan 18 perlakuan, dengan percobaan rancangan acak kelompok atau RAK karena kedua kelompok diberi satuan percobaan yang berbeda. Kedua kelompok dianestesi umum menggunakan ketamin, kemudian dibuat masingmasing satu perlukaan pada punggung dengan panjang dan lebar $15 \times 15 \mathrm{~mm}$ serta kedalaman $2 \mathrm{~mm}$. Pada kelompok kontrol diberikan bahan dasar gel, sedangkan pada perlakuan diaplikasikan ekstrak etanol daun mengkudu segera setelah dibuat perlukaan. Kedua kelompok lalu diberikan bahan topikal sesuai dengan kelompoknya pada punggung sebanyak satu kali setiap hari sampai diterminasi, untuk dibuat sediaan histopatologis dari setiap tikus pada hari ke-3, ke-7, dan ke-14 (masing-masing 6 tikus). Sediaan histopatologis untuk kedua kelompok pada masing-masing hari pengamatan diberi pewarnaan hematoksilin 
eosin (HE), pewarnaan imunohistokimia CD34, dan pewarnaan kolagen van Gieson. Jumlah sel fibroblas dinilai secara kuantitatif, sedangkan untuk sel inflamasi, persentase imunohistokimia CD34 dan persentase kolagen dipakai penilaian semikuantitatif. Cut-off point untuk persentase CD34 dan kolagen masing-masing berdasarkan penelitian oleh Goel dkk. ${ }^{15}$ dan Suckow dkk. ${ }^{16}$ (Tabel 1). Analisis statistik yang dipergunakan adalah uji 2 kelompok tidak berpasangan MannWhitney untuk semua parameter. Penelitian ini telah mendapatkan persetujuan etik dari Komite Etik Penelitian Kesehatan Fakultas Kedokteran Universitas Padjadjaran Bandung.

\section{Hasil}

Fibroblas dan juga sel inflamasi yang merupakan penyusun jaringan granulasi pada penelitian ini dipergunakan sebagai parameter pembentukan jaringan granulasi dengan memakai pewarnaan HE. Pengamatan yang dilakukan pada sediaan hari ke-3, jumlah sel fibroblas rata-rata lebih banyak ditemukan pada kelompok perlakuan dibandingkan dengan kelompok kontrol. Pada kedua kelompok, sel-sel fibroblas di jaringan baru terlihat masih jarang. Pada sediaan hari ke-7 didapatkan jumlah sel fibroblas rata-rata lebih banyak pada kelompok perlakuan dibandingkan dengan kelompok kontrol, sedangkan serabut kolagen sudah mulai terlihat pada sediaan kedua

\section{Tabel 1 Penilaian Semikuantitatif untuk 3} Parameter Penelitian

\begin{tabular}{lc}
\hline Variabel & Skor \\
\hline Sel inflamasi & \\
$\quad$ Tidak ada & 0 \\
Sedikit (fokal) & 1 \\
Sedang (difus, jarang) & 2 \\
$\quad$ Banyak (masif, difus, padat) & 3 \\
Persentase imunohistokimia & \\
CD34 (\%) & \\
$<20$ & 1 \\
$20-50$ & 2 \\
$50-80$ & 3 \\
$>80$ & 4 \\
Persentase kolagen (\%) & \\
$<25$ & 1 \\
$25-50$ & 2 \\
$51-75$ & 3 \\
$>75$ & 4 \\
\hline
\end{tabular}

kelompok. Pada pengamatan sediaan hari ke14 , jumlah sel rata-rata pada sediaan perlakuan sedikit lebih banyak daripada kelompok kontrol (Tabel 2). Beberapa sel terutama pada kelompok perlakuan sudah menunjukkan maturasi menjadi fibrosit. Sel epitel yang mulai menutupi sebagian permukaan luka terlihat pada kedua kelompok (Gambar 1).

Pada sediaan hari ke-3 pada kedua kelompok, infiltrasi sel inflamasi terlihat jelas terutama pada permukaan luka. Sel-sel pada hari ke-3 tersebut umumnya terdiri atas polimorfonuklear (PMN) dan limfosit. Pengamatan pada sediaan hari ke-7 menunjukkan infiltrasi sel inflamasi pada kedua kelompok sebagian besar berdistribusi difus. Terlihat infiltrasi sel-sel inflamasi akut yang jelas dan makrofag yang mulai bermigrasi ke jaringan luka tersebar bersamaan dengan sel-sel fibroblas. Pada kelompok kontrol, selsel inflamasi akut lebih terlihat dominan bila dibandingkan dengan makrofag. Infiltrasi selsel inflamasi yang tersebar di permukaan luka masih terlihat pada sediaan hari ke-14 pada kelompok kontrol dan sebagian kecil kelompok perlakuan, namun sudah semakin berkurang bila dibandingkan dengan sediaan hari ke-7 (Tabel $3)$.

Ekspresi positif CD34 ditandai dengan warna coklat pada sediaan. Hasil pengamatan sediaan hari ke-3 memperlihatkan bahwa pada kedua kelompok, sel dan jaringan dengan ekspresi CD34 positif yang merupakan tanda awal pembentukan kapiler baru dan migrasi sel progenitor endotel dari vaskular sudah mulai muncul, sedangkan mikrovaskularisasi belum terlihat. Pada sediaan hari ke-7 selain masih memperlihatkan migrasi sel progenitor endotel, kapiler yang baru terbentuk juga mulai tampak pada kedua kelompok, dengan sebaran endotel kapiler baru yang lebih jelas terlihat pada kelompok perlakuan. Pengamatan sediaan pada hari ke-3 dan ke-7 memperlihatkan bahwa jaringan dengan hasil CD34 positif lebih banyak terlihat pada kelompok perlakuan bila dibandingkan dengan kelompok kontrol tetapi perbedaannya tidak besar, sedangkan sediaan hari ke-14 sebaran jaringan dengan CD34 positif yang ditemukan pada kedua kelompok adalah sama (Tabel 3). Hasil pengamatan ini menunjukkan bahwa jumlah sel progenitor endotel di jaringan yang bermigrasi dan berdiferensiasi menurun seiring dengan terbentuknya endotel (Gambar 2).

Deposisi kolagen yang terjadi pada jaringan granulasi akan terlihat berwarna merah terang pada sediaan tersebut berupa kolagen berbentuk serabut (tipe III) dan pita/band (tipe I). Pada hari ke-3 baik kelompok kontrol maupun perlakuan 
Tabel 2 Jumlah (Mean) Sel Fibroblas

\begin{tabular}{lccc}
\hline Jumlah Sel Fibroblas & Hari 3 & Hari 7 & Hari 14 \\
\hline Kontrol & $12,167(2,87)$ & $46,5(14,10)$ & $88,3(12,81)$ \\
$\begin{array}{l}\text { Perlakuan (ekstrak daun } \\
\text { mengkudu) }\end{array}$ & $15,167(2,87)$ & $64(14,10)$ & $93,6(12,81)$ \\
\hline
\end{tabular}

memperlihatkan hanya sedikit deposisi kolagen. Pengamatan sediaan hari ke-7 menunjukkan pada kelompok perlakuan, deposisi kolagen sedikit lebih banyak bila dibandingkan dengan kelompok kontrol, namun pada kedua kelompok susunan serabutnya belum teratur. Deposisi kolagen pada sediaan kelompok perlakuan hari ke-14 tampak serabutnya lebih padat bila dibandingkan dengan kontrol. Pada sediaan hari ke-14 kedua kelompok juga lebih banyak ditemukan kolagen matur (tipe I) yang berbentuk pita dibandingkan dengan hari ke-7 (Tabel 3, Gambar 3).

Hasil analisis statistik memakai Uji MannWhitney pada nilai kepercayaan 95\% $(\mathrm{p}<0,05)$ menggunakan perangkat lunak statistical product and service solutions (SPSS) versi 17.0 adalah $\mathrm{p}=0,319$ (jumlah sel fibroblas), $\mathrm{p}=0,290$ (sel inflamasi), $\mathrm{p}=0,251$ (persentase CD34), serta $\mathrm{p}=0,245$ (persentase kolagen). Hasil penelitian menunjukkan bahwa perbedaan antara kelompok kontrol dan perlakuan terlihat pada data, namun secara statistik tidak bermakna.

\section{Pembahasan}

Penyembuhan pada luka merupakan suatu proses fisiologis yang terjadi di tubuh sebagai respons terhadap jejas. Proses penyembuhan di kulit merupakan contoh umum yang menggambarkan prinsip penyembuhan luka tersebut di sebagian besar jaringan. Umumnya untuk melihat proses yang melibatkan sel dan jaringan ini dilakukan eksperimen secara in vivo. Luka eksisi merupakan jenis luka sekunder karena ada jarak antara kedua tepi luka. Karena perlukaan pada luka eksisi termasuk luka berat, model eksisi secara in vivo dapat lebih jelas lagi memperlihatkan perubahan

Tabel 3 Pengamatan Daerah Infiltrasi Sel Inflamasi, CD34, dan Kolagen

\begin{tabular}{lccccccc}
\hline & \multicolumn{6}{c}{ Skor Kontrol } & \multicolumn{5}{c}{ Skor Perlakuan (Ekstrak Daun Mengkudu) } \\
\cline { 2 - 8 } & Sediaan & Hari ke-3 & Hari ke-7 & Hari ke-14 & Hari ke-3 & Hari ke-7 & Hari ke-14 \\
\hline Infiltrasi & 1 & 2 & 3 & 3 & 2 & 2 & 1 \\
sel & 2 & 1 & 3 & 2 & 2 & 2 & 2 \\
& 2 & 3 & 3 & 2 & 2 & 2 & 1 \\
& 3 & 1 & 2 & 1 & 2 & 2 & 2 \\
& 4 & 2 & 2 & 2 & 2 & 3 & 2 \\
CD34amasi & 5 & 2 & 3 & 3 & 1 & 3 & 3 \\
& 6 & 1 & 3 & 4 & 1 & 2 & 3 \\
& 1 & 1 & 3 & 3 & 1 & 3 & 4 \\
& 2 & 1 & 1 & 3 & 2 & 4 & 3 \\
& 3 & 3 & 2 & 3 & 2 & 1 & 2 \\
& 4 & 3 & 2 & 2 & 3 & 4 & 3 \\
& 5 & 1 & 2 & 3 & 3 & 4 & 3 \\
& 6 & 1 & 2 & 3 & 1 & 3 & 4 \\
& 1 & 1 & 2 & 3 & 1 & 2 & 3 \\
& 2 & 1 & 2 & 3 & 1 & 3 & 4 \\
& 3 & 1 & 2 & 2 & 1 & 2 & 4 \\
& 4 & 1 & 1 & 3 & 1 & 2 & 3 \\
\hline
\end{tabular}



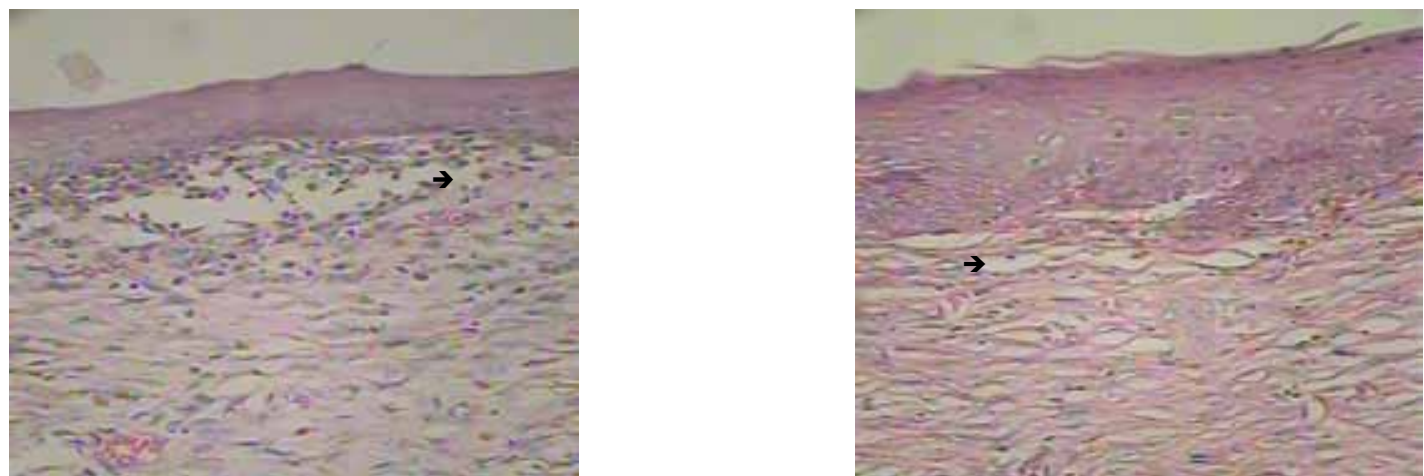

\section{Gambar 1 Hasil Pengamatan HE Hari ke-14 (Pembesaran 400x)}

Kiri: Kontrol; Kanan: Perlakuan. Pada kelompok perlakuan sel inflamasi (tanda panah) sudah lebih berkurang dibandingkan dengan kelompok kontrol
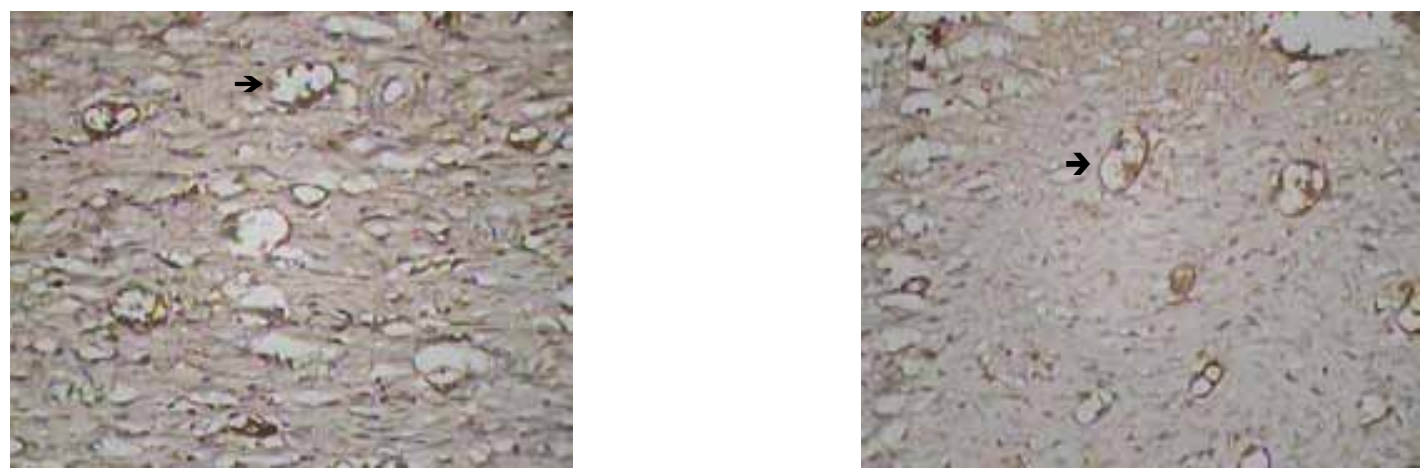

\section{Gambar 2 Hasil Pengamatan Imunoekspresi CD34 Hari ke-14 (Pembesaran 400x)}

Kiri: Kontrol; Kanan: Perlakuan. Pada kelompok kontrol, imunoekspresi CD34 masih terdapat di jaringan yang ditandai dengan warna coklat, sedangkan pada kelompok perlakuan sudah terpusat pada endotel (tanda panah)
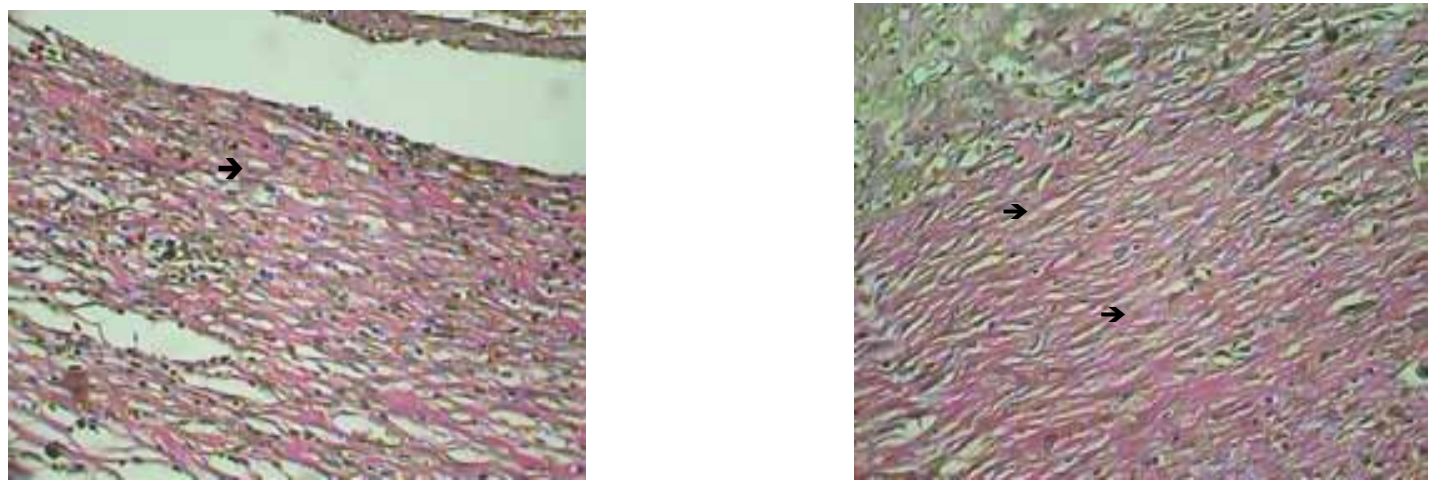

\section{Gambar 3 Hasil Pengamatan Kolagen Hari ke-14 (Pembesaran 400x)}

Kiri: Kontrol; Kanan: Perlakuan. Warna merah yang menandakan kolagen (tanda panah) lebih terlihat jelas dan padat pada kelompok perlakuan 
jaringan dan selular yang berhubungan dengan perbaikan luka. Selain itu, hewan pun masih dapat hidup dan beraktivitas seperti biasa walaupun telah dibuat perlukaan. Secara garis besar proses penyembuhan luka ini terdiri atas tiga fase yang mekanisme kejadiannya terjadi saling tumpang tindih dengan fase-fase selanjutnya yaitu fase inflamasi, fase proliferasi, dan remodeling. Peran ekstrak etanol daun mengkudu topikal pada akhir fase inflamasi, fase proliferasi, dan awal fase remodeling diobservasi pada penelitian ini. ${ }^{4,9,17}$

Hasil penelitian pemberian ekstrak etanol daun mengkudu per oral sebelumnya terbukti membantu penyembuhan luka secara bermakna pada beberapa parameter yaitu penurunan infiltrasi sel inflamasi, peningkatan jumlah dan maturasi protein kolagen, juga peningkatan epitelialisasi, neovaskularisasi, peningkatan jumlah fibroblas, dan mempercepat kontraksi luka. Pada penelitian tersebut flavonoid, triterpen, dan glikosida iridoid dinyatakan sebagai zat aktif yang paling berperan dalam membantu proses penyembuhan luka. . $^{2,5}$

Jaringan granulasi ialah jaringan ikat muda yang mengisi perlukaan terdiri atas fibroblas, pembuluh darah baru, dan juga sel inflamasi yang didominasi oleh makrofag. Pada penelitian ini jumlah sel fibroblas dan juga tingkat infiltrasi sel inflamasi digunakan untuk menandai kemajuan penyembuhan luka yaitu melalui pembentukan jaringan granulasi dengan pemeriksaan secara histologis. ${ }^{3,4}$ Pada penyembuhan luka, jaringan granulasi mulai terbentuk sejak sekitar hari ke-3 menggantikan matriks provisional bekuan darah. Fibroblas berasal dari sel-sel punca yang terdapat pada lamina propria kulit, kemudian bermigrasi dan berproliferasi dengan terdapatnya sitokin dan faktor pertumbuhan yang disekresi oleh trombosit dan makrofag saat terjadi luka terutama transforming growth factor- $\beta$ (TGF- $\beta$ ) dan basic fibroblast growth factor (bFGF). Sekresi bFGF dari makrofag dan juga dari fibroblas meningkat pada hari ke-7-14 pascaperlukaan sejalan dengan jumlah fibroblas yang meningkat pada periode tersebut. ${ }^{3,17}$ Hasil penelitian ini memperlihatkan pada kelompok perlakuan hari ke-3, ke-7, dan juga ke-14, jumlah sel fibroblas yang ditemukan lebih banyak dibandingkan dengan kelompok kontrol, namun secara statistik perbedaannya tidak bermakna. Jumlah fibroblas rata-rata pada kelompok perlakuan lebih banyak dibandingkan dengan kontrol terutama pada fase proliferasi, kemungkinan berasal dari efek senyawa flavonoid dan glikosida iridoid pada daun mengkudu yang menghambat ekspresi tumor necrosis factor- $\alpha$ $(\mathrm{TNF}-\alpha)$ dari makrofag. Peran TNF- $\alpha$ adalah untuk memediasi migrasi sel PMN, apoptosis sel fibroblas, dan sintesis matriks metaloproteinase (MMP). Dari suatu penelitian diketahui flavonoid juga dapat meningkatkan ekspresi reseptor insulinlike growth factor-1 (IGF-1) sebagai mediator proliferasi fibroblas dan sintesis kolagen. Selain itu, flavonoid dan glikosida iridoid juga mampu menghambat pengeluaran enzim degradatif dari sel neutrofil sehingga pada kelompok perlakuan tidak terjadi kerusakan sel fibroblas yang lebih banyak. ${ }^{2,8,18}$

Infiltrasi sel-sel inflamasi pada penyembuhan luka terjadi dalam waktu 24 jam setelah terjadi jejas. Pada luka eksisi, infiltrasi sel inflamasi ini tampak lebih jelas dibandingkan dengan luka insisi. Sel inflamasi pertama yang berespons pada penyembuhan luka adalah neutrofil, kemudian diikuti dengan monosit yang mulai memasuki jaringan dan berdiferensiasi menjadi makrofag serta memenuhi perlukaan hari ke-3 setelah luka. ${ }^{4}$ Pada penelitian ini di kedua kelompok, makrofag baru terlihat jelas pada sediaan hari ke-7. Data hasil pengamatan memperlihatkan infiltrasi sel inflamasi pada kelompok perlakuan sebarannya lebih sedikit bila dibandingkan dengan kelompok kontrol. Kemungkinan hal ini disebabkan efek antiinflamasi dari flavonoid dan glikosida iridoid daun mengkudu dengan menghambat pengeluaran TNF- $\alpha$ dari makrofag yang mencetuskan migrasi sel PMN dan saponin sebagai antibakteri yang mencegah jejas berulang karena bakteri dapat memperpanjang siklus proinflamasi. ${ }^{4,8,18}$

Pembentukan pembuluh darah baru merupakan proses penting dalam penyembuhan luka yang melibatkan faktor pertumbuhan terutama VEGF dan platelet derived growth factor (PDGF), serta sel progenitor endotel. Protein CD34 merupakan jenis protein transmembran yang diekspresikan pada progenitor dan punca hematopoetik, selain diekspresikan pada endotel vaskular. Ekspresi positif CD34 pada jaringan baru yang mengisi perlukaan adalah penanda bahwa pada perlukaan terjadi migrasi sel-sel progenitor pembentuk endotel dari sumsum tulang ke dalam sirkulasi melalui pembuluh darah yang rusak, kemudian akan bermigrasi ke jaringan granulasi sebelum akhirnya berdiferensiasi menjadi endotel yang matur. Migrasi sel progenitor pembuluh darah baru ini dipengaruhi oleh VEGF yang dikeluarkan sel makrofag saat pembuluh darah mengalami kerusakan dan hipoksia, umumnya sekitar 6-12 jam setelah jejas. ${ }^{14}$ Dari pengamatan terhadap sediaan hari ke-3 pascaperlukaan, belum terlihat endotel matur yang menandakan angiogenesis, namun ekspresi positif CD34 terlihat pada sekitar $20 \%$ jaringan granulasi.

Pada sediaan hari ke-7, ekspresi positif CD34 pada jaringan granulasi bertambah menjadi 50 $80 \%$ pada kelompok perlakuan, disertai dengan beberapa gambaran endotel matur yang juga terekspresi positif CD34. Hal ini memperlihatkan 
bahwa pada fase proliferasi, walaupun proses angiogenesis berlangsung, sel progenitor ataupun sel punca endotel masih terdapat pada beberapa bagian di jaringan baru.

Pada kelompok perlakuan hari ke-7 ternyata persentase ekspresi positif CD34 tampak lebih banyak dibandingkan dengan kelompok kontrol yang memperlihatkan peningkatan jumlah dan migrasi sel progenitor pembentuk endotel dengan pemberian ekstrak etanol daun mengkudu topikal. Pengamatan yang dilakukan pada sediaan hari ke-14 memperlihatkan pada kedua kelompok, bagian jaringan yang terekspresi positif CD34 berkurang dibandingkan dengan hari ke-7. Pada kedua kelompok ditemukan persentase jaringan dengan imunoekspresi positif yang sama. Secara statistik tidak terlihat perbedaan yang bermakna antara kedua kelompok. Hal ini kemungkinan disebabkan karena mulai hari ke-7-14, dengan ekstrak etanol daun mengkudu topikal, migrasi sel progenitor endotel pada kelompok perlakuan lebih cepat mencapai taraf maksimal, karena sifat antiinflamasi ekstrak yang didapat dari senyawa flavonoid ataupun glikosida menyebabkan pada akhir fase proliferasi jumlah makrofag lebih cepat menurun sehingga VEGF yang dihasilkan makrofag sebagai faktor kemotaksis sel progenitor endotel sudah tidak direkrut lagi. Pada kelompok perlakuan diperkirakan sifat antioksidan senyawa aktif daun mengkudu juga mencegah kerusakan endotel luas yang menyebabkan hipoksia. Hal ini sebagai stimulasi faktor angiogenik. ${ }^{2,4,5}$

Serabut kolagen pada proses perbaikan luka mulai terlihat pada hari ke-3 pascaperlukaan yang terjadi di sekitar tepi luka tersebut, terutama yang dimediasi pengeluarannya oleh IL-4 dari sel makrofag. Selanjutnya, pada fase proliferasi, kolagen mulai disintesis oleh fibroblas dengan dirangsang oleh TGF- $\beta$ dari sel makrofag dan fibroblas sendiri, terutama kolagen tipe III yang berbentuk serabut. Deposisi kolagen yang terlihat pada fase ini tersusun secara acak. Pada fase remodeling yaitu hari ke-14 pascaperlukaan, sintesis kolagen tipe III mulai digantikan oleh kolagen tipe I yang berbentuk pita dan memiliki kekuatan regang lebih kuat. Reorganisasi susunan kolagen dan cross-linking kolagen yang terjadi pada fase remodeling memberikan kekuatan dan kepadatan jaringan baru. Pengamatan mengenai serabut kolagen di hari ke-3 menunjukkan pada kelompok kontrol dan perlakuan, baru ditemukan sedikit kolagen, oleh karena pada fase inflamasi jumlah fibroblas masih belum maksimal sehingga faktor pertumbuhan yang dihasilkan juga belum berperan. ${ }^{3,4,17}$ Dari hasil penelitian ini didapatkan deposisi kolagen pada kelompok perlakuan lebih tinggi bila dibandingkan dengan kontrol, namun tidak bermakna secara statistik. Deposisi kolagen yang lebih banyak ditemukan pada kelompok perlakuan, hal ini kemungkinan mekanismenya disebabkan oleh efek antioksidan dari flavonoid pada daun mengkudu yang membantu pencegahan kerusakan jaringan oleh radikal superoksida yang dilepaskan oleh sel neutrofil. Efek antiinflamasi yang didapat dari flavonoid dan glikosida iridoid juga mampu menghambat pengeluaran enzim degradatif dari neutrofil yang dapat menghambat pengikatan-silang kolagen. Diduga peningkatan sintesis kolagen juga disebabkan efek flavonoid terhadap reseptor IGF-1 di fibroblas. Selain itu, efek antibakteri saponin kemungkinan berperan dalam mengoptimalkan pembentukan kolagen kelompok perlakuan, dengan mencegah kerusakan jaringan akibat bakteri dan produknya. Hal ini juga dapat menstimulasi respons inflamasi. ${ }^{4,6,8,18}$

Hasil penelitian ini memperlihatkan ekstrak etanol dari daun mengkudu cenderung membantu penyembuhan luka apabila dilihat dari parameter yang diteliti, akan tetapi berdasarkan statistik tidak bermakna. Keadaan ini berbeda dengan penelitian terdahulu oleh Nayak dkk. ${ }^{2}$ yang menyatakan bahwa pada pemberian per oral yang berbeda bermakna terhadap kontrol. Kemungkinan yang dapat menyebabkan hasil yang tidak bermakna secara statistik pada penelitian ini di antaranya dengan dosis ekstrak etanol topikal yang kurang, terdapat intervensi subjek lain, misalnya ekstrak yang sudah diaplikasikan pada punggung tikus dikonsumsi oleh tikus-tikus lain, cara pemberian ekstrak dengan menggunakan bahan dasar gel, dan pemberian topikal sifatnya lebih superfisial jika dibandingkan dengan pemberian per oral.

Pada hasil penelitan ini membuktikan tanpa ada pengobatan yang sesuai, fase-fase penyembuhan yang terjadi setelah terjadi luka dapat terhambat dan memanjang. Diharapkan ekstrak etanol daun mengkudu topikal dapat digunakan sebagai obat bahan alam yang dapat dipakai dengan aman dan bermanfaat pada penyembuhan luka. Walaupun mekanisme zat aktif ekstrak etanol dari daun mengkudu terhadap penyembuhan luka dapat dijelaskan melalui keterangan yang didapat dari literatur dan penelitian-penelitian sebelumnya, namun pada penelitian lain dapat dilakukan untuk mengetahui zat aktif mana yang lebih spesifik berperan dalam proses ini.

\section{Daftar Pustaka}

1. Peterson L. Contemporary oral and maxillofacial surgery. Edisi ke-4. St. Louis: CV Mosby Co; 2004.

2. Nayak BS, Sandiford S, Maxwell A. Evaluation of the wound-healing activity of ethanolic extract of Morinda citrifolia L. leaf. 
eCAM. 2009;6(3):351-6.

3. Kumar V, Abbas AK, Fausto N. Robbins and Cotran's pathologic basis of disease. Edisi ke-7. Philadelphia: Saunders; 2003.

4. Granick MS, Gamelli RL. Surgical wound healing and management. New York: Informa; 2007.

5. Rasal VP, Sinnathambi A, Ashok P, Yeshmaina S. Wound healing and antioxidant activities of Morinda citrifolia leaf extract in rats. IJPT [Online Journal] 2008 [diunduh 4 Juli 2010]. Tersedia dari: http://ijpt.iums.ac.ir.

6. Wang M, West BJ, Jensen CJ, Nowicki D, S Chen, Palu A, dkk. Morinda citrifolia (Noni): A literature review and recent advances in noni research. Acta Pharmacol Sin. 2002; 23 (12): 1127-1141.

7. West BJ, Deng S, Palu AK, Jensen CJ. Morinda citrifolia Linn. (Rubiaceae) leaf extracts mitigate UVB-induced erythema. Jour Nat Med. 2009 [diunduh 7 Juni 2010]. Tersedia dari: http://www.springerlink.com.

8. Meskin MS, Bidlack WR, Davies AJ, Lewis DS, Randolph RK. Phytochemicals mechanisms of action. Boca Raton: CRC Press; 2004.

9. Doss A, Mubarack HM, Dhanabalan R. Antibacterial activity of tannins from the leaves of Solanum trilobatum Linn. Ind Jour Sci Tech. 2009; 2(2): 41-43.

10. Suwiti NK. Deteksi histologik kesembuhan luka pada kulit pasca pemberian daun mengkudu (Morinda citrifolia Linn.). Buletin Veteriner Udayana [Online Journal] Februari 2010 [diunduh 26 Juni 2010]. Tersedia dari: $\mathrm{http}: / / \mathrm{www} \cdot$ bulletinveteriner.com.

11. Esimone CO, Nworu CS, Jackson CL. Cutaneous wound healing activity of a herbal ointment containing the leaf extract of Jatropha curcas L. (Euphorbiaceae). Int J Appl Res Nat Prod [Online Journal] 2008 [diunduh 28 Juni 2010]. Tersedia dari: http:// www.healthy-synergies.com.

12. Szpaderska AM, Zuckerman JD, DiPietro LA. Differential injury responses in oral mucosal and cutaneous wounds. J Dent Res. 2003; 82(8): 621-626.

13. Trubiani O, Tripodi D, Delle Fratte T. Human dental pulp vasculogenesis evaluated by CD34 antigen expression and morphological arrangement. J Dent Res. 2003; 82(9): 742747.

14. Guo X, Liu L, Zhang M, Bergeron A, Cui Z, Dong J, dkk. Correlation of CD34+ cells with tissue angiogenesis after traumatic brain injury in a rat model. J Neurotrauma. 2009; 26(8): 1337-1344.

15. Goel MM, Agrawal D, Natu SM, Goel A. Hepsin immunohistochemical expression in prostate cancer in relation to Gleason's grade and serum prostate specific antigen. Indian $\mathbf{J}$ Pathol Microbiol. 2011; 54: 476-481.

16. Suckow MA, Hodde JP, Wolters WR, Hiles MC. Use of porcine renal capsule matrix as a full-thickness dermal wound-healing material in rats. J. Wound Care. 2005; 14: 137-140.

17. Schultz GS, Ladwig G, Wysocki A. Extracellular matrix: review of its roles in acute and chronic wounds. World Wide Wounds [Online Journal] 2005 [diunduh 15 Juni 2010]. Tersedia dari: http://www. worldwidewounds.com.

18. Middleton E, Kandaswami C, Theoharides CT. The effects of plant flavonoids on mammalian cells: implications for inflammation, heart disease, and cancer. Pharm Rev. 2000; 52: 673-751. 